\title{
Local partnerships in the social security system of the region
}

Ph.D. Anna Łoś-Tomiak University of Zielona Gora

\section{Introduction}

Satisfying the needs of the residents at the expected level, attention to the quality of social services, appropriate distribution of resources and an effective system of entities performing tasks in this respect, is the basis for the determination of the state of social security of the region.

Shaping the optimum level of security is more and more frequently and effectively implemented thanks to local partnerships, defined primarily by the interaction of local public administration and NGOs. Both groups of subjects perform tasks for the benefit of the local communities, care about the welfare of the community and complement the implementation of social policy in the region. Through the lens of the two, you can see the development of the idea of civil society, a selforganizing society for which the imperative is the idea of social responsibility for yourself, the family, group and community, which, guided by the principles of the common good and solidarity, identifies the needs of local communities and groups and aims at their efficient implementation with their own actions and the organization of resources for this purpose. The efficiency of interaction of the entities forming civil society depends 
mainly on the defined goals, preferences, and the expected effect. Its positive effect is related to the proper specifying measures of success, methods of mutual control and transparent policy to each other and the community, and most of all of trust based on honesty and openness in communication (Zaheer 1998, ss. 141-159).

The aim of this article is to identify the state of social security of the region through the lens of the local cross-sector partnerships, implemented by NGOs and local government units and to show action practices in this regard, on the example of Zielona Gora.

\section{Cross-sector partnership}

The local government defines the individual and collective needs of the local. It determines the current purposes and goals of the community, the redistribution of budget resources, or selecting the beneficiaries of the implemented projects. It manages all kinds of issues of individual units, market entities, civil and public ones. It specifies the development of strategic plans and policy objectives of short and medium-term objectives of the municipality. It administers public funds, human resources and organizational and institutional entities which it may use to implement the mandatory commissioned and own tasks. In addition, drafting local legislation and regulations is at the discretion of the local government.

Apart from local government structures, the contractor of social tasks for the benefit of the community, improvement of the quality and standard of living and meeting the needs of the citizens are non-governmental organizations, which as an independent, self-governing, durable entities, materialize the social purpose the best. Diversifying the sources of funding, and also submitting the maximum return on the action taken on limiting costs, they are the most effective in the implementation of such tasks. Third sector entities comply with the contents of these areas of social life that are not interesting for market operators or public institutions. For the market, profit is the primary motive, therefore, being unable to find meaning in the tasks not guaranteeing an adequate rate of return on investment, they are not involved in projects of this type. However, the public sector, though in a way obliged to act in this regard, is often inefficient and insufficiently effective in meeting social needs, especially if they make a niche. Functioning of public institutions is defined by rigid operating procedures, excessively large administration and very limited budget, which significantly reduces the level of service provided and the degree of fulfilment of the mission. 
Therefore, to ensure the expected level of social security of the region, it is desirable to create a stable system based on parity and partnership pages. Partnership treated as interaction, not depriving autonomy, based on respect, transparency, responsibility, determinate by the community purposes, according to the competence of both parties (Brinkerhoff 2012, ss. 19-30).

Non-governmental organizations and local government are natural units and the closest partners in promoting local communities and determining the level of social security. They are combined by both the population and the region, thus there is a convergence of needs, for which they undertake operations, but they also have the same motive of activities - care for the common good of the citizens. For the local public administration, which is both the public authority and the representation of the local community, the need to meet the needs of the community is the responsibility of, and focus on the common good allows you to achieve the objective. And the beneficiaries of the initiatives, not only consume the benefits resulting from the implementation of the common good, but they also deem the care for them reasonable and necessary and take an active part in the selection of local elites.

The common objective and subordination of actions, of both local administration and civic institutions, the needs of the local community, determines the inter-local partnership, regarded as "a platform for cooperation between the different partners who together, in a systematic, sustainable way and using innovative methods and means of planning, design, implement and carry out specific activities and initiatives aimed at developing the local socioeconomic development and construction of local identity among members of the community“ (Sobolewski, Krzewicka, Och, Olszowska-Urban, Piekutowski, Podławiak, Sobolewski 2007, s. 10), constituting a basis for developing and maintaining the state of social security in the region. So defined, reaching county and municipalities, partnership for the local community, has a wide dimension. About the partnership, in the narrower sense, may also constitute initiative for particular task or project (Geddes 2001, s. 5).

The partnership of citizens, local authorities and local government structures implemented in socio-economic policy is not only good practice activities, but is also legitimate. Its foundation can be a constituted social dialogue, which, treated as a partnership of citizens in decision making and system satisfying social needs, gives formal consent for common goals and actions. Defined most frequently through the lens of a system of work and related to the relationship of employers and employees, it is also used in justifying the support of the effective functioning of local and regional partnerships, as "... it includes all 
types of negotiation, consultation or a simple exchange of information between representations of governments, employers and workers on issues relating to the interest of their economic and social problems. The dialogue can be implemented as a tripartite process with the government as an official participant, or may relate to the bilateral relations between labour and management (or trade unions and employers' organizations) with or without the participation of the government. Harmonizing interests may be informal or institutionalized and most often is, both such and such. This can be done at the national, regional or company level. It can take place between the representations of different professional groups within sectors, or by combining both planes"(Gardawski 2009, 17).

Also the constitutional principle of subsidiarity, according to which "the responsibility for public affairs should be borne primarily by those authorities which are the closest to the citizens. Allocation of responsibility to another authority should weigh up the extent and the nature of the task and requirements of efficiency and economy. The powers given to local authorities should normally be full and exclusive and can be undermined or limited by another authority, central or regional, only to the extent provided by law" (Subsydiarnośc..., 2012, s. 5). Thus, the power to represent and meet their own needs, belong in the first place, to individuals and social groups, and only then to the local authorities and the state which should not relieve or restrict efforts of citizens in self-realization and self-organization - provides the basis for cooperation and equality of the parties. In accordance with the principle of subsidiarity, the main function of government is to satisfy the needs within its community or people shaping their own destiny and take responsibility for, but unable to fully develop. (...) As a legal principle, subsidiarity indicates that the rights and freedoms of individuals are the source of all rights and obligations of the community. (...) The principle of subsidiarity can be reduced to two basic postulates relating to the relationship: individual-community and -state: as much freedom as you can; as much socialization as necessary, and as much society, as can be; and much state as necessary" (Popławska 2006, s. 148, 149).

Besides, the participation of individuals and formalised groups in the decisionmaking system and the implemented local policy, justifies the right to organize and form representation for their own interests and needs. This is the basis for the recognition of equality and partnership of the interested entities and it obliges the parties to identify and mutually respect their rights and obligations.

The relationship between the non-governmental sector ii public can take many different forms. The nonprofit entities can demonstrate a strong and substantive economic independence and can be a viable opposition to the public sector in 
the creation of different goods and services. They can also perform challenges on behalf of the local public administration, which is associated with full or partial funding. They can also be an equal partner of the public sector in developing local policies and cooperate with in the performance of public duties (Salamon 2001).

The principles of cooperation and relations between the local partners of the social system, which are primarily local government units and non-governmental organizations, are mainly determined by the Law on Public Benefit and Volunteer Work. According to it, the local government and local authorities are required to cooperate with non-governmental sector, in the forms proposed by the legislature, or by the parties. The Act deprived the public administration of the right to discretion in choosing a partner in the implementation of public tasks for the public benefit. It allowed for the committed involvement of citizen entities in the social security system of the region on equal principles with public entities.

The principles of cooperation and relations between the local partners of the social system, which are primarily local government units and nongovernmental organizations, are mainly determined in the Law on Public Benefit and Volunteer Work. According to it, the government and local authorities are required to cooperate with the non-governmental sector, in the forms proposed by the legislature, or by the parties. The Act deprived the public administration of the right to discretion in choosing a partner in the implementation of public tasks of public benefit. It allowed the involvement of citizen subjects in the social security system of the region on an equal footing with the public entities.

The practice of bilateral contacts indicates that the forms of cooperation provided by the legislature, are applicable and partners rarely use other forms. The care of the socio-economic development of regions, implemented by the local government units, in cooperation with non-profit institutions, means mainly commissioning public tasks under the terms of the Act, supported with full funding, i.e. entrusting or funding specific projects. Other frequently used forms of cooperation include exchange of information on planned directions of activity, as well as consultation with NGOs normative acts in the areas relating to statutory activities of these organizations, consultations on draft legislation concerning public tasks, the creation of joint teams for advising and taking initiatives or entering into contracts for local initiative under the terms of the Act and concluding partnership agreements set forth in the Act on principles of development policy (Act ..).

It should be emphasized that local cross-section partnerships, formally defined or not, are based on annually enacted cooperation programmes, to which 
entities are obliged by law. The programmes determine the form of the planned contacts, the scope of activities, areas and framework for cooperation of the local administration, NGOs and the budget provided for that.

\section{Cooperation of Zielona Gora City with non-governmental organizations of the region}

An example of successfully implemented local partnership is the cooperation between the non-governmental organizations and the city of Zielona Gora. It runs effectively both in financial and non-financial fields. It is based, in accordance with the law, on the programmes prepared each year, the implementation of which is reported by the parties. The financial cooperation mainly includes: entrusting and assigning the non-governmental organizations the implementation of public tasks in an open tender procedure, and since 2012 - assigning and ordering them to perform their public tasks in a simplified non-competition mode - through the provision of the so-called small grants. The financial cooperation can also take the form of the support for the implementation of public tasks in the form of a local initiative, outsourcing jobs in other modes, primarily on the basis of public procurement law or giving the non-governmental institutions, implementing public tasks, loans and guarantees.

Also the substantive cooperation in the form of consultation, mutual information, planning and organization of activities firmly establishes and determines the quality of cooperation.

The city of Zielona Gora performs the duty of cooperation with the nongovernmental sector willingly and in an increasing range. However, the share of the public resources in the implementation of tasks in different areas of determining the state of the social security in the region differs.

Table 1. Public expenditure in different areas of the activity

\begin{tabular}{l|c|c|c|c|c|c}
\hline \multirow{2}{*}{$\begin{array}{l}\text { Area of activ- } \\
\text { ity }\end{array}$} & 2010 & 2011 & \multicolumn{2}{|c|}{2012} & \multicolumn{2}{|c}{2013} \\
\cline { 2 - 7 } & - & - & $\begin{array}{c}\text { by compe- } \\
\text { tition }\end{array}$ & $\begin{array}{c}\text { non-compe- } \\
\text { tition mode }\end{array}$ & $\begin{array}{c}\text { by competi- } \\
\text { tion }\end{array}$ & $\begin{array}{c}\text { non-compe- } \\
\text { tition mode }\end{array}$ \\
\hline $\begin{array}{l}\text { Culture, art, } \\
\text { protection } \\
\text { of cultural } \\
\text { heritage and } \\
\text { traditions }\end{array}$ & 632500 & 326000 & 493700 & 18900 & 769130 & 57000 \\
\hline
\end{tabular}


Vol.18, No. 2

\begin{tabular}{|c|c|c|c|c|c|c|}
\hline $\begin{array}{l}\text { Promoting } \\
\text { physical } \\
\text { culture }\end{array}$ & 4305000 & 3281200 & 3 230960.80 & 64950 & 3591400 & 8000 \\
\hline $\begin{array}{l}\text { Education, } \\
\text { school } \\
\text { system and } \\
\text { upbringing }\end{array}$ & 236822 & 284900 & 295974 & - & 297500 & - \\
\hline $\begin{array}{l}\text { Tourism and } \\
\text { touring }\end{array}$ & 36000 & 55500 & 26000 & - & 18900 & 14100 \\
\hline $\begin{array}{l}\text { Promotion and } \\
\text { protection of } \\
\text { health }\end{array}$ & 209000 & 456500 & 427500 & 20000 & 427500 & 10000 \\
\hline $\begin{array}{l}\text { Public safety } \\
\text { and the } \\
\text { prevention } \\
\text { of social } \\
\text { pathologies }\end{array}$ & 181100 & 176200 & 411500 & - & 471000 & - \\
\hline $\begin{array}{l}\text { Cooperation } \\
\text { with partner } \\
\text { and fellow } \\
\text { cities }\end{array}$ & 121233 & 100000 & 65186 & 19800 & 91436 & 8500 \\
\hline $\begin{array}{l}\text { Addiction } \\
\text { prevention, } \\
\text { in particular } \\
\text { against } \\
\text { psychoactive } \\
\text { substances }\end{array}$ & 408470 & 342788 & 335000 & 22978,97 & 328609 & 13019 \\
\hline $\begin{array}{l}\text { Ecology } \\
\text { and animal } \\
\text { protection }\end{array}$ & 433000 & 449000 & 493000 & 10000 & 554000 & - \\
\hline $\begin{array}{l}\text { Social } \\
\text { assistance }\end{array}$ & - & - & 1335155.50 & 35000 & 1370970 & 30000 \\
\hline Disability & - & - & - & 7700 & - & 6500 \\
\hline Total & 6563125 & 5472088 & 6276510.80 & 199328.97 & 7920445 & 147119 \\
\hline
\end{tabular}

Source: own study based on reports on the implementation of the programmes of Zielona Gora with NGOs in 2009-2013 
The highest level of funding refers to the tasks related to sports and physical culture. The amounts allocated for this purpose are much higher than those spent in other areas. In 2013 also a dramatic increase of the number of organizations participating in the programmes was noticed - there were 116 of them, whereas in previous years there were 60 of them. This reflects also in the ratio of the number of those benefiting from public funding, goods and services. When analysing the amount of public funding in the implementation of tasks in the area of sport and tourism, it may be expected that the high level of budgetary expenditure will maintain, and even grow. The trend line is presented at the level of 0.3 .

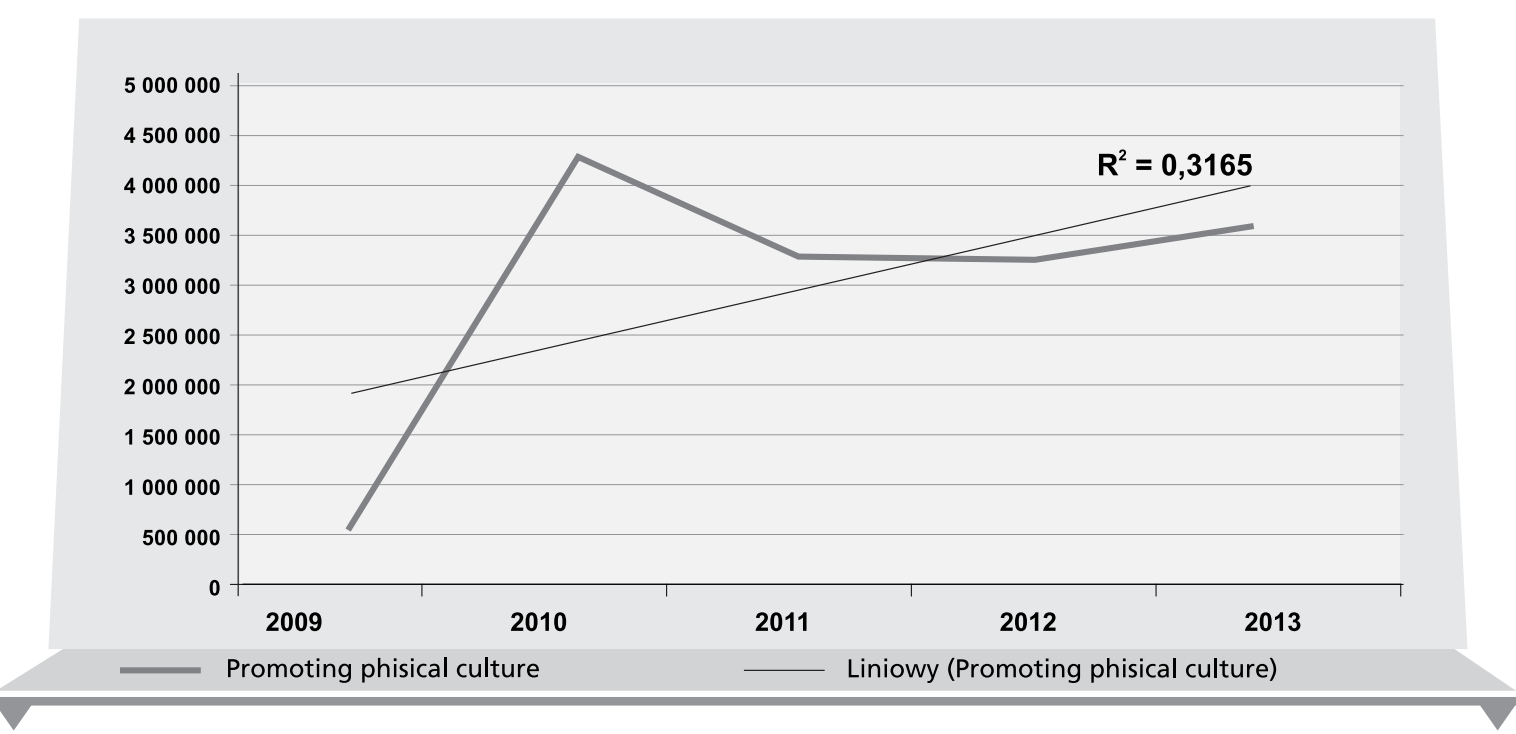

Figure 1. Expenditure in the area: promoting physical culture

Source: own study based on reports on the implementation of the programmes of Zielona Gora with NGOs in 2009-2013

On a much smaller level of funding, but quite high in the scale of the total expenditure, are the tasks related to the protection of cultural heritage and traditions and the culture and art in a wide meaning. The number of nongovernmental organizations carrying out public tasks is increasing - from 35 and 27 to 59 in the year 2013. The number of beneficiaries implementing public tasks in this regard is also increasing. The trend line defined for expenditure in the area is at the level of 0.1 , which does not allow to determine the direction of change. 


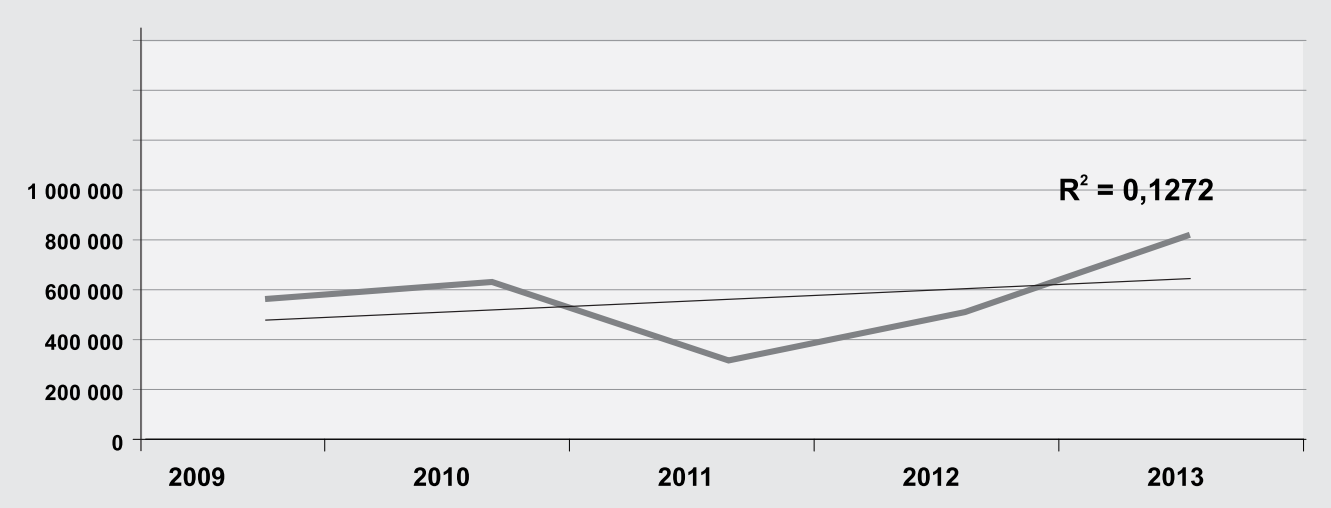

Expenditure in the area of Culture, art, protection of cultural heritage and traditions Liniowy (Expenditure in the area of Culture, art, protection of cultural heritage and traditions)

Figure 2. Expenditure in the area of culture, art, protection of cultural heritage and traditions

Source: own study based on reports on the implementation of the programmes of Zielona Gora with NGOs in 2009-2013

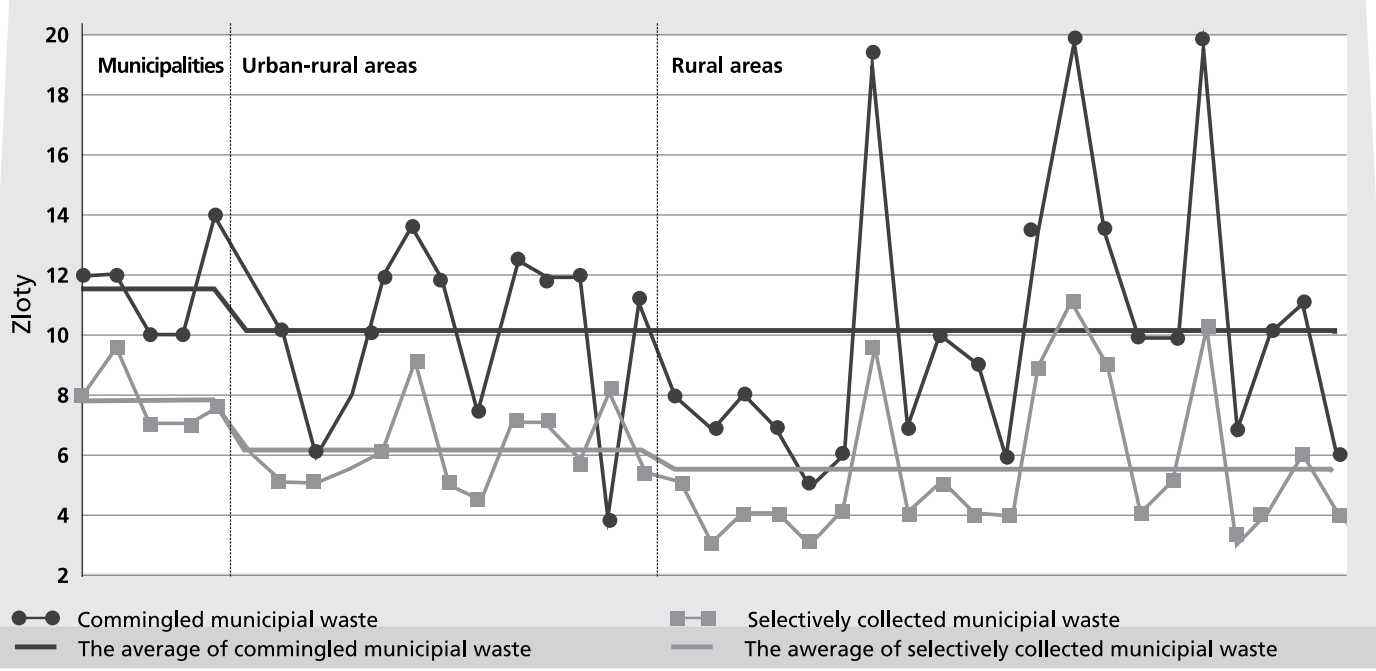

Figure 3. The fee per person for the commingled and selectively collected municipal wastein the Świętokrzyskie Region in 2013

Source: own research 
The share of public funds in the area of research, education, school system and childcare is similar in the analysed period. The amounts of funding are similar, they are in the range of approx. 236 thousand to nearly 300 thousand. Based on trend analysis, one should not expect changes in any direction. Especially that, looking at the average, the number of beneficiaries of the programmes implemented is also similar, despite an increase in the number of non-governmental entities cooperating with the local government of the city in this area (from 45 in 2009 to 82 in 2013).

In financing of public tasks performed by, or in cooperation with the non-governmental sector, you can also observe a strong positive change. The determined trend lines suggest that in subsequent periods, the share of public funds in the tasks in the following areas will be growing, although the share of the amounts allocated for this purpose, the total budget, is not impressive.

The non-governmental organizations in number from 30 (2009), to 20 (2013) consumed public funds in the area of health promotion and protection. The number of beneficiaries, lower in the years 2009-2010 - at the level of 7-8 thousand, rose to 12,400 in 2012 and 11,100 in 2013. The trend of nearly 0.6, despite a mild decrease in funding in recent years, is growing.

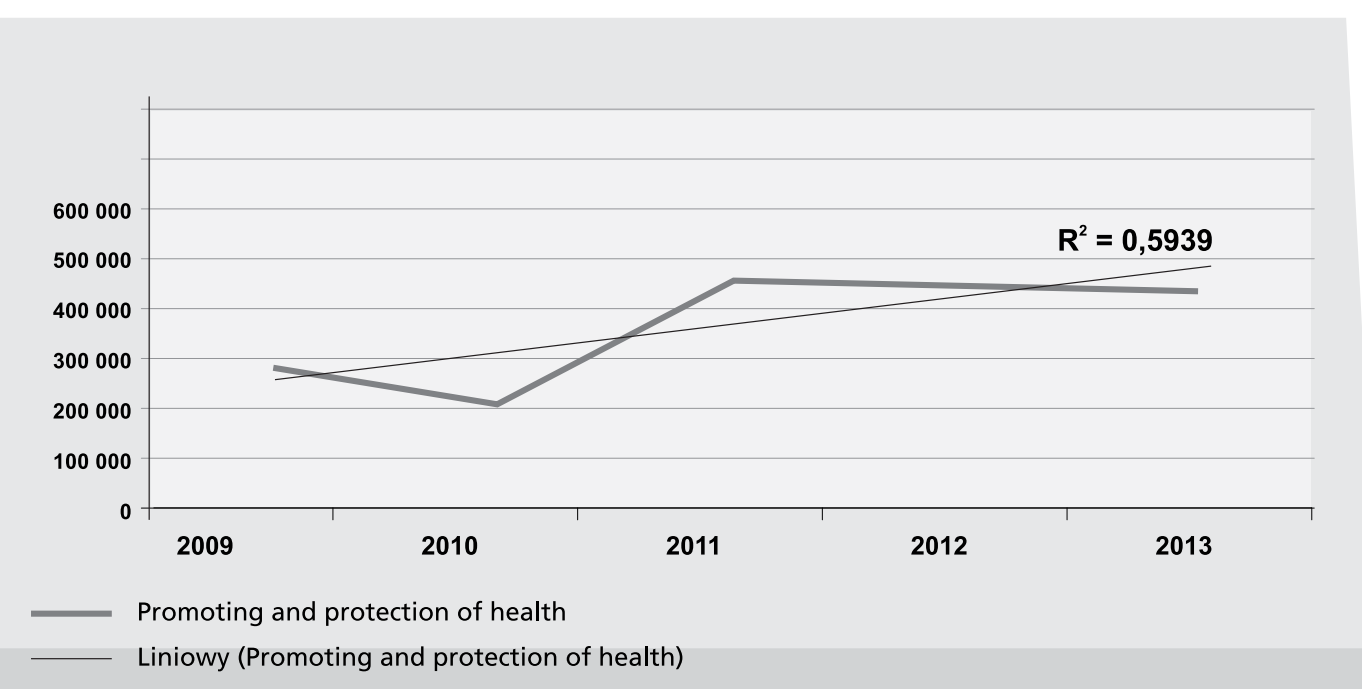

Figure 4. Expenditure in the area of: Promotion and protection of health

Source: own study based on reports on the implementation of the programmes of Zielona Gora with NGOs in 2009-2013 


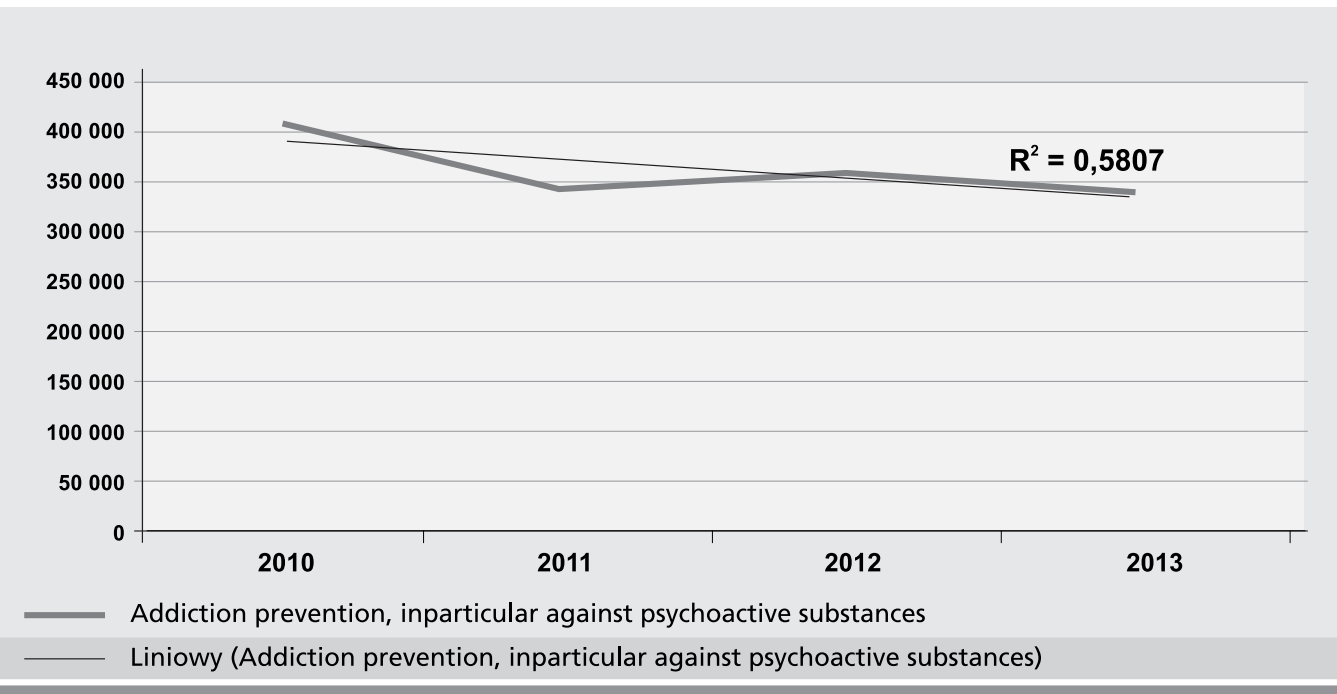

Figure 5. Addiction prevention

Source: own study based on reports on the implementation of the programmes of Zielona Gora with NGOs in 2009-2013

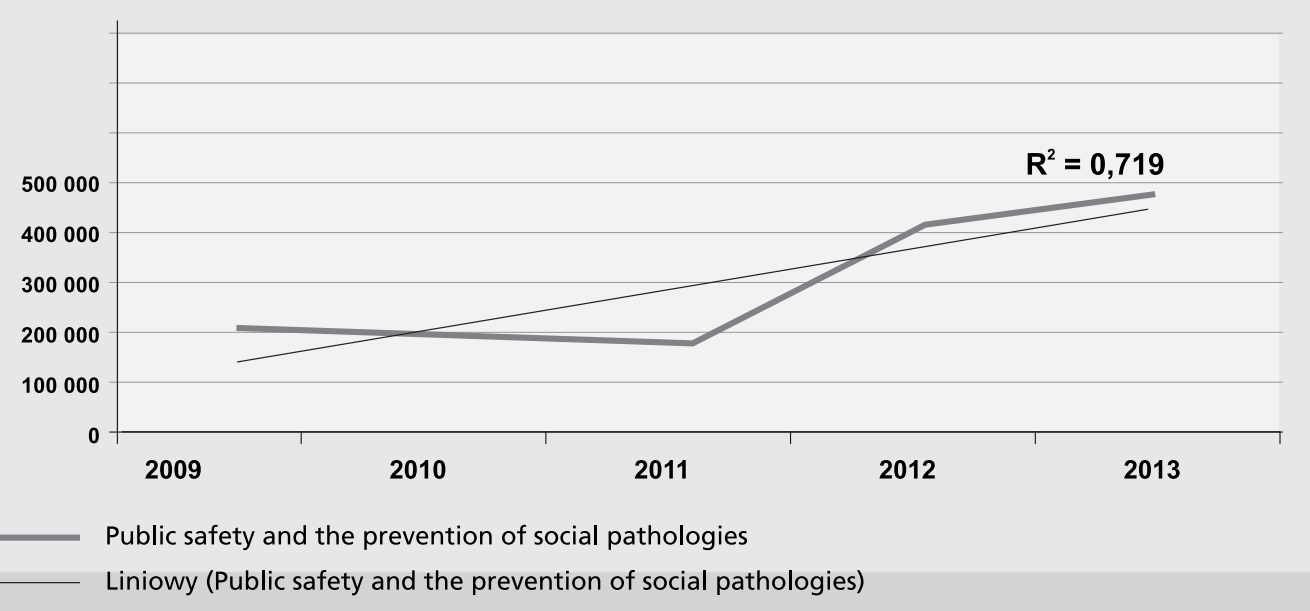

Figure 6. Expenditure in the area of: Public safety and the prevention of social pathologies

Source: own study based on reports on the implementation of the programmes of Zielona Gora with NGOs in 2009-2013 
A very similar situation is with reference to the activities in the field of addiction, in particular to psychoactive substances. It can be anticipated that the share of public expenditure in accordance with the trend line defined at the level of close to 0.6 , it will be growing, with a decreasing number of beneficiaries of the tasks - from 9000 in 2009 to 6417 in 2013.

The activity of non-governmental organizations in the field of public safety is worth emphasizing. The implementation of tasks related to the reduction of related risks and prevention of social pathologies, was interesting to 42 non-governmental organizations in 2013 - in the previous periods it was dealt with by: 14 entities in 2010 and 19, 20 in the next two years. The number of people using the services of non-profit entities also significantly increased - from 16,630 in 2010, through only 6200 and 8902, to 75,700 in the year 2013. The trend line set at a level above 0.7 , determines the ascending trend.

\section{Conclusion}

The cooperation between NGOs and the public sector, which have similar goals and motives, has measurable benefits for individuals, groups and local communities. The execution of the tasks of public nature, thanks to the participation of non-profit organizations, is more effective, at a higher level and cheaper and includes a larger group of customers and provides the basis for a maximum return on investment.

Analysis of data on the local government cooperation with NGOs, on the example of Zielona Gora, allows high assessment of the role of local partnerships in the social security system in the region. The growing share of non-governmental sector in the implementation of the tasks of public benefit is proof that all the participants of the programmes, both providers and payers, and beneficiaries, are satisfied with the applied solutions. It should be assumed that NGOs have become a recognized and equal social partner for the local administration.

\section{Abstract}

\section{Local partnerships in the social security system of the region}

This paper looks at the state of social security through the lens of the local cross-sector partnerships. The foundations of cooperation undertaken by NGOs and the local government have been determined. The analysis was made on the example of the cooperation between the city of Zielona Gora and the NGO sector in the years 2009-2013. 
Key words: local partnerships, NGOs, local government.

\section{Streszczenie}

\section{Partnerstwo lokalne $\mathrm{w}$ systemie bezpieczeństwa społecznego regionu}

W artykule dokonano interpretacji stanu bezpieczeństwa społecznego przez pryzmat lokalnego partnerstwa międzysektorowego. Określone zostały podstawy współpracy podejmowanej przez organizacje pozarządowe i samorząd terytorialny, ze wskazaniem na współpracę finansową. Analizy dokonano na przykładzie współdziałania miasta Zielonej Góry i sektora pozarządowego, w latach 2009-2013.

\section{Słowa}

kluczowe: partnerstwo lokalne, organizacje pozarzadowe, samorzad terytorialny, wspótpraca

\section{References}

1. Bogacz-Wojtanowska E. (2013), Zdolności organizacyjne a współdziałanie organizacji pozarządowych, Instytut Spraw Publicznych Uniwersytetu Jagiellońskiego w Krakowie, Kraków.

2. Brinkerhoff J.M. (2012), Government-Nonprifit partnership. A defining Framework, w: „Publick Administration and Development”, vol. 22.

3. Gardawski J. (2009), Dialog społeczny w Polsce. Teoria, historia, praktyka, MPiPS, Warszawa.

4. Geddens M., Benington J. (2001), Local partnership and social exclusion In European Union: new forms of local social governance, London.

5. Popławska E. (2006), Wpływ zasady subsydiarności na przemiany ustrojowe w Polsce, w: D. Milczarek red., Subsydiarność, Centrum Europejskie Uniwersytetu Warszawskiego, Warszawa.

6. Salamon L.M. (2001), The nonprofit sector and democracy: prerequisite, impediment, or irrelevance?, (w:) Abramson A.J. (red.), Mapping new worlds. Selected research on the nonprofit sector around the globe, Nonprofit Sector Research Fund of the Aspen Institute, Washington D.C.

7. Sobolewski A., Krzewicka R., Och G., Olszowska-Urban J., Piekutowski J., Podławiak G., Sobolewski T. (2007), Przez wspótprace do sukcesu. Partnerstwo lokalne na rynku pracy, ZWP MPiPS, Warszawa.

8. Sprawozdanie z realizacji „Programu współpracy Miasta Zielona Góra z organizacjami pozarządowymi za rok 2013. 
9. Sprawozdanie z realizacji „Programu współpracy Miasta Zielona Góra z organizacjami pozarządowymi za rok 2012.

10. Sprawozdanie z realizacji „Programu współpracy Miasta Zielona Góra z organizacjami pozarządowymi za rok 2011.

11. Sprawozdanie z realizacji „Programu współpracy Miasta Zielona Góra z organizacjami pozarządowymi za rok 2010.

12. Sprawozdanie z realizacji „Programu współpracy Miasta Zielona Góra z organizacjami pozarządowymi za rok 2009.

13. Subsydiarność w prawie i praktyce samorządowej (2012), Kancelaria Senatu. Biuro Analiz i Dokumentacji, Warszawa.

14. Ustawa o pożytku publicznym i o wolontariacie, Dz.U. 2003 nr 96 poz. 873.

15. Zaheer, A., McCevilly, B. i Perrone V. (1998). Does Trust Matter? Exploring the Effects of Interorganizational and Interpersonal Trust on Performance. Organization Science: A Journal of the Institute of Management Sciences, 92. 